\title{
Design of Seeder in Relation to the Physical and Frictional Properties of Groundnut Varieties
}

\author{
Korla Harshavardhan ${ }^{1}$, S. S. Sivakumar ${ }^{1 *}$, J. John Gunasekar ${ }^{2}$, \\ P. K. Padmanathan ${ }^{1}$ and V. Alex Albert ${ }^{3}$ \\ ${ }^{1}$ Department of Farm Machinery and Power Engineering, ${ }^{2}$ Department of Renewable \\ Energy Engineering, ${ }^{3}$ Department of Basic Engineering and Applies Sciences, AEC\&RI, \\ Kumulur, India \\ *Corresponding author
}

K e y w o r d s
$\begin{aligned} & \text { Seeder, Coefficient } \\ & \text { of static friction, } \\ & \text { Physical properties, } \\ & \text { Groundnut, } \\ & \text { Sphericity }\end{aligned}$
Article Info
Accepted:
04 October 2020
Available Online:
10 November 2020

\section{Introduction}

Groundnut (Arachis hypogaea L.) is an important oilseed crop in India which

occupies first in terms of area and second
Physical and frictional properties of groundnut seeds play an essential role in designing a seeder in order to decide cell size, shape, thickness of metering disc and material, inclination of seed hopper. The present study aimed to determine the physical and frictional properties of groundnut seeds of three varieties viz., VRI 8, CO 6 \& TMV 7. Length, breadth, thickness, roundness, thousand seed weight, geometric mean diameter, sphericity were evaluated for designing metering disc of seeder. Bulk density, true density, angle of repose, coefficient of restitution and coefficient of static friction were evaluated for designing seed hopper of seeder. Cell diameters and thickness of the seed metering discs were designed based on the maximum breadth and length of seeds. Seed flow through the various components of the seeder was affected by both roundness and sphericity. Roundness of VRI 8, CO 6 and TMV 7 were $0.49,0.47$ and 0.53respectively, while sphericity in the natural rest position of these seeds were $0.71 \pm 0.05,0.70 \pm 0.09$ and $0.73 \pm 0.09$ respectively. The slope of the seed hopper was fixed at $30^{\circ}$, which is moderately higher than the average angle of repose of seeds for ensuring free flow of seeds. Mild steel sheet of material grade Fe 410 and 18 gauge i.e., $1.214 \mathrm{~mm}$ thickness is selected for seed hopper in reference to the coefficient of static friction to other materials (Al, GI, SS \& wood). In addition, the inner bottom surface of the seed hopper from where the seed enters into metering disc was imbedded with $3 \mathrm{~mm}$ thick rubber sheet as its coefficient of restitution was lower than mild steel sheet of same thickness at different heights. It was observed that the average coefficient of restitution values of three varieties (VRI 8, CO 6 \& TMV 7) were 5.0, 1.8, 1.2, 1.2, 1.3\&1.4times lower in rubber sheet compared to MS sheet at the heights of 50,100,150, 200, 250 \& $300 \mathrm{~mm}$ respectively. position in terms of production. China is the largest producer as well as consumer of groundnut in the world with 166.24 lakh tonnes followed by India (68.57 lakh tonnes), Nigeria (30.28 lakh tonnes) and United States 
(25.78 lakh tonnes). As per APEDA data, India's groundnut kernel shipment declined and is at 3.57 lakh tonnes during AprilDecember 2018 amounting total Rs. 2,394 crore. This was lower than the corresponding figures of 3.88 lakh tonnes and Rs 2,647 crore during last year. The country exported total 5.04 lakh tonnes of groundnut kernel in 2017 18 (April-March) valued Rs. 3,386.30 crore. Around 50 per cent of our peanut exports are to Indonesia, Vietnam, Philippines and Malaysia, with the remaining being exported to China, Russia Ukraine and United Kingdom (Directorate General of Commercial Intelligence and Statistics (DGCIS)).

According to SEA report, groundnut crop area in India is at 40.12 lakh ha in 2018-19 down from 41.35 lakh ha in last year. Similarly, production and yield are estimated at 37.70 lakh tonnes and $931 \mathrm{~kg} / \mathrm{ha}$ respectively as against 52.75 lakh tonnes and $1269 \mathrm{~kg} / \mathrm{ha}$ respectively during previous year. According to the all India rabi crop coverage report, Government of India, as on 7th February 2019 groundnut has been sown in around 4.81 lakh hectares, which was 23.28 per cent lower than the corresponding period of last year (6.27 lakh ha). Among the states, Tamil Nadu stood first in area coverage with 1.26 lakh ha followed by Telangana (1.07 lakh ha), Odisha (0.91 lakh ha) and Karnataka (0.72 lakh ha).

In India still sowing with seeder is not practicing even though many researchers are suggesting that sowing with machinery will provide better yields and consume less time. One of the main reasons for this condition is unavailability of economically viable groundnut sowing machinery for farmers in Indian market. In view of this, the seeder which can sow groundnut seeds as per requirement should be developed for precise sowing. To achieve this, suitable metering mechanism with appropriate cell geometry for metering seeds and suitable material for seed hopper with proper dimensions are essential which can be designed by studying the physical and frictional properties of seeds. Hence the study on "Design of seeder in relation to the physical and frictional properties of groundnut varieties" has been contemplated.

The physical properties and frictional properties are useful and necessary in the design and operation of various farm equipments employed for agricultural operations (Sahay and Singh, 1994). The important physical and frictional properties which are directly related to the seeder development, were determined in the present study. The knowledge of physical and frictional properties is important for design, development and efficient operation of a seeder.

Seed flow through a planter or seeder is dependent on physical and frictional properties of seeds. In addition, the impact of seeds on the internal components of the planter is influenced by the coefficient of restitution of seeds on various impinging surfaces. Basic information on these properties is of great importance and help for engineers and scientists towards the equipment development and its efficient operation.

Since the size and shape of many local varieties vary from each other, attempts were made to find out the optimum design parameters of a seeder by determining the relevant physical and frictional properties of three varieties of groundnut seeds (VRI 8, CO 6\&TMV 7).

These three varieties are selected in such a way that these varieties should cover all the districts of Tamil Nadu as well as which can sow in all the three seasons i.e., kharif, Rabi and Zaid seasons (TNAU Agri portal, 2019). 


\section{Materials and Methods}

Seeds of three groundnut varieties viz., VRI 8 , CO 6 \& TMV 7 were selected for determining the physical and frictional properties. The samples for testing were selected randomly from the bulk samples of each variety.

\section{Physical properties of groundnut seeds}

Physical properties of groundnut seeds such as moisture content, length, width, thickness, geometric mean diameter, aspect ratio, sphericity, roundness, thousand seed weight, bulk density, true density are important for design of metering mechanism and seed hopper of seeder in order to decide the size, thickness, cell size of metering disc and capacity of seed hopper. Hence the physical properties of three varieties of groundnut viz., VRI 8, CO 6\& TMV 7were determined by using standard procedure and techniques.

\section{Moisture Content (MC)}

The moisture content of groundnut seeds was determined using thermogravimetric method. With the help of electronic weighing balance initial weights of samples were recorded. Three replications of each variety were dried in hot air oven at temperature of $105 \pm 2$ (ASAE, 1994). At 6 hrs intervals the samples had been weighed until the weights of the samples were found to be constant. The moisture content of groundnut seeds was calculated by using following relationship.

$M C(\% d b)=\frac{w 1-w 2}{w 2} \times 100$

(Hand book of agricultural engineering., 2013)

Here,
$\mathrm{W} 1=$ Weight of the wet sample $(\mathrm{g})$

$\mathrm{W} 2=$ Weight of the dry sample $(\mathrm{g})$

\section{Size of groundnut Seeds}

For estimating the size, with the help of digital vernier callipers $(0.01 \mathrm{~mm}$ precision $)$, principle dimensions such as length $(\mathrm{L})$, width (W) and thickness (T) were recorded. The measurement was replicated for 100 samples of each variety and their means were computed (Aydin, 2007; Bamgboye and Adebayo, 2012; Krishnappa, 2017).

\section{Geometric mean diameter $\left(D_{g}\right)$}

The length (L), width (W) and thickness (T) measured for 100 samples of were used to calculate geometric mean diameter $\left(\mathrm{D}_{\mathrm{g}}\right)$ with the following relationship.

$D_{g}=(L \times W \times T)^{\frac{3}{3}}$

(Bahnasawy, 2007; Mohsenin, 1986)

\section{Aspect Ratio (R)}

The aspect ratio $(\mathrm{R})$ is the ratio of width (W) and length (L) as following relation.

$R=\frac{W}{L} \ldots \ldots \ldots \ldots(3)$

(Davies, 2009)

\section{Sphericity}

The degree of sphericity $(\phi)$ was determined using the following equation.

$\emptyset=\frac{(L \times W \times T)^{\frac{1}{3}}}{L} \ldots \ldots \ldots \ldots(4)$

(Mohsenin, 1986; Singh et al., 2010)

\section{Roundness}

Roundness is a measure of the sharpness of the corners of solid materials. The roundness 
of irregular particle was determined by most widely accepted method. Ten samples of each variety were taken and the shape of seed at its natural rest position was traced on paper. The smallest circumscribing circle was constructed on each tracing paper and the diameter of circle was noted. The area of the smallest circumscribing circle (Ac) was calculated and the largest projected area (Ap) of each sample was measured using a planimeter. Then the roundness was determined using the following expression;

Roundness $=\frac{A_{p}}{A_{c}} \ldots \ldots \ldots$...... (5)

(Sahay and Singh, 1994; Maduako and Hamman, 2005)

Here,

$A_{p}=$ Largest projected area of groundnut seed in natural rest position, $\mathrm{mm}^{2}$

$\mathrm{A}_{\mathrm{c}}=$ Area of smallest circumscribing circle, $\mathrm{mm}^{2}$

\section{Thousand seed weight}

Thousand seed weight was determined for 10 random samples of 1000 seeds each (per seed variety) using an electronic balance having sensitivity of $0.01 \mathrm{~g}$.

(Davies, 2009; Balasubramanian et al., 2011; Sharma et al., 2011)

\section{Bulk density $\left(\rho_{b}\right)$}

A $10 \times 10 \times 10 \mathrm{~cm}$ box was filled with groundnut seeds and weighed using an electronic weighing machine of $0.01 \mathrm{~g}$ accuracy. The trails were repeated 10 times using different varieties of seeds and the bulk density was calculated from the following equation.

$\rho_{b}=\frac{M}{V}, g \mathrm{~cm}^{-3}$
(Maduako and Hamman., 2004; Karaj and Muller., 2010)

Here,

$\mathrm{M}=$ Mass of the seed, $\mathrm{g}$ $\mathrm{V}=$ Volume of sampler, $\mathrm{cm}^{3}$

\section{True density $\left(\rho_{t}\right)$}

True density of seeds was calculated as

$\rho_{x}=\frac{\text { Bulk density }}{1-\text { Porosity }}, \mathrm{Kg} \mathrm{m}^{-3} \ldots \ldots \ldots$ (7)

(Hand book of agricultural engineering., 2013)

For this, porosity was determined using a standard porosity apparatus with ten replicates.

\section{Frictional properties of groundnut seeds}

The frictional properties such as angle of repose, coefficient of static friction and coefficient of restitution are important in designing of hoppers, chutes, conveying systems etc. of the planters or seeders. In mechanical and pneumatic conveying systems, the materials generally move or slides in direct contact with the trough, casing and other components of the machine. Thus, various parameters affect the power requirement to drive the machine. Among these parameters, the frictional losses are one of the factors which must be overcome by providing additional power to the machine. Hence, the knowledge of frictional properties of the agricultural materials is necessary; therefore, following frictional properties of the groundnut pods were determined as explained below.

\section{Angle of repose $(\theta)$}

The angle of repose of seeds was determined by the following method. The seeds were 
allowed to fall from a height of $300 \mathrm{~mm}$ on circular discs of 250, 200and 100mm diameter until maximum height was reached and the height of seed heap was noted. The experiment was replicated ten times for each seed variety and the average values were computed. The following equation was used to calculate the angle of repose of the selected seeds.

$\theta=\tan ^{-1} \frac{h}{r} \ldots \ldots . . . . .(8)$

(Wazari and Mittal., 1983)

Here

$\mathrm{h}=$ height of cone $(\mathrm{mm})$

$\mathrm{r}=$ radius of cone $(\mathrm{mm})$

\section{Coefficient of static friction $(\mu)$}

Coefficient of static friction is a measure of resistance, determined for selecting hopper material for uniform and free flow of seeds. The static coefficient of friction $(\mu)$ was determined for five structural materials namely plywood, aluminium, mild steel, stainless steel and galvanized iron sheet. An amount 250 grams of sample was placed on the block (Normal force) and it was pulled across the plane at a constant speed by adding load at the end (Frictional force). The force required to create "bump" which pulls the seeds was noted. Static coefficient of friction $(\mu)$ is the ratio of frictional force to the normal force. The procedure was repeated 10 times for each variety and the mean value was calculated.

$\mu=\frac{F}{N} \ldots \ldots . . . . . .(9)$

(Sahay and Singh, 1994; Balasubramanian, 2011; Bahnasawy, 2007)

Here,

$\mathrm{F}=$ Frictional force (force applied)

$\mathrm{N}=$ Normal force (weight of the grain)

\section{Coefficient of restitution}

Coefficient of restitution of seeds was determined by the following method. In this method, a seed is dropped from a height of $50,100,150,200,250$ and $300 \mathrm{~mm}$ on a $3 \mathrm{~mm}$ thick mild steel and rubber sheets. A graduated scale of $500 \mathrm{~mm}$ was kept at the background and the maximum height of seed rebounce recorded using a high-speed digital video camera. Height of rebounce was measured in the monitor using the video editing unit. This was replicated 10 times for each seed variety and the coefficient was calculated using the following equation.

Coef ficient of restitution $=\sqrt{\frac{h}{H}} \ldots \ldots \ldots \ldots$ (10)

(Jayan and Kumar., 2006; Kumar., 1995)

Here

$\mathrm{h}=$ height of rebound $(\mathrm{mm})$

$\mathrm{H}=$ height of drop ( $\mathrm{mm})$

\section{Results and Discussion}

Results show that VRI 8, CO 6 and TMV 7 variety seeds were $12.28 \pm 1.74,13.86 \pm 2.68$ and $11 \pm 1.91 \mathrm{~mm}$ long and $7.88 \pm 1.42,8.68$ \pm 1.20 and $7.25 \pm 1.29 \mathrm{~mm}$ wide respectively (Table 1). Accordingly, the seed metering discs were fabricated with cell diameter of $10 \mathrm{~mm}$ and a plate thickness of $10 \mathrm{~mm}$ which can suit most varieties of groundnut seed. This is expected to meter 1 to 2 seeds when the metering disc cell hole overlaps with the hopper hole. The thickness of each cell in metering wheel was designed in such a way that it can meter only single seed. Movement of non-spherical seed is usually slower under gravity. Sphericity of VRI 8, CO 6\& TMV 7 in natural rest position were $0.71 \pm 0.05,0.70$ \pm 0.09 and $0.73 \pm 0.09$ respectively. Since the metered seeds are to be transferred to the seed placement unit quickly, the lower sphericity 
value of groundnut seeds should be taken into consideration for designing the slope of seed transfer cup. Here the sphericity of all three varieties are almost equal. Again, seed weight effects seed flow from seed metering device to the boot of seeder and in turn, influences the design of seed hopper. Although Bulk density of all 3 variety of seeds was almost same highest value was found in TMV7 $\left(0.63 \mathrm{~g} / \mathrm{cm}^{3}\right)$ followed by CO $6\left(0.62 \mathrm{~g} / \mathrm{cm}^{3}\right)$ and VRI $8\left(0.61 \mathrm{~g} / \mathrm{cm}^{3}\right)$. The mean angle of repose of VRI 8, CO 6 \& TMV 7 were 23.15 , 23.87 and $24.38^{\circ}$ respectively (Fig. 1).

Table.1 Physical and frictional properties of groundnut seeds

\begin{tabular}{|c|c|c|c|c|}
\hline \multirow[t]{2}{*}{ Sl. No. } & \multirow[t]{2}{*}{ Parameters } & \multicolumn{3}{|c|}{ Groundnut seed varieties } \\
\hline & & VRI 8 & CO 6 & TMV 7 \\
\hline \multirow[t]{5}{*}{1.} & \multicolumn{4}{|l|}{ Size and Shape } \\
\hline & Length $(\mathrm{mm})$ & $12.28 \pm 1.74$ & $13.86 \pm 2.68$ & $11.00 \pm 1.91$ \\
\hline & Breadth $(\mathrm{mm})$ & $7.88 \pm 1.42$ & $8.68 \pm 1.20$ & $7.25 \pm 1.29$ \\
\hline & Thickness (mm) & $7.10 \pm 0.40$ & $7.60 \pm 1.00$ & $6.59 \pm 1.21$ \\
\hline & Geometric mean diameter $(\mathrm{mm})$ & $9.09 \pm 0.24$ & $9.71 \pm 1.11$ & $8.07 \pm 1.19$ \\
\hline 2. & Moisture content (\% db) & 7.90 & 7.08 & 8.10 \\
\hline 3. & Roundness & 0.49 & 0.47 & 0.53 \\
\hline 4. & Aspect ratio & 0.65 & 0.63 & 0.66 \\
\hline 5. & Sphericity & $0.71 \pm 0.05$ & $0.70 \pm 0.09$ & $0.73 \pm 0.09$ \\
\hline 6. & Bulk density (g/cm3) & 0.61 & 0.62 & 0.63 \\
\hline 7. & True density $(\mathrm{kg} / \mathrm{m} 3)$ & 1772 & 1905 & 1801 \\
\hline 8. & Angle of repose $\left(^{0}\right)$ & 23.15 & 23.87 & 24.38 \\
\hline \multirow[t]{6}{*}{9.} & \multicolumn{4}{|c|}{ Coefficient of static friction for different materials } \\
\hline & Aluminium & 0.48 & 0.46 & 0.50 \\
\hline & Galvanized iron & 0.51 & 0.51 & 0.51 \\
\hline & Mild steel & 0.42 & 0.39 & 0.45 \\
\hline & Stainless steel & 0.39 & 0.32 & 0.46 \\
\hline & Wood & 0.56 & 0.48 & 0.64 \\
\hline 10. & Thousand seed weight (g) & $427.69 \pm 5.77$ & $421.11 \pm 2.29$ & $429.08 \pm 6.44$ \\
\hline
\end{tabular}

$(95 \%$ confidence limit $=$ mean $\pm 1.645 \mathrm{SD})$

Table.2 Coefficient of restitution of groundnut seeds at different dropping heights

\begin{tabular}{|l|l|c|c|c|c|c|c|}
\hline Seeds & Impact surface & \multicolumn{6}{|c|}{ Coefficient of restitution at different dropping heights } \\
\cline { 3 - 9 } & (3mm thickness) & $50 \mathrm{~mm}$ & $100 \mathrm{~mm}$ & $150 \mathrm{~mm}$ & $200 \mathrm{~mm}$ & $250 \mathrm{~mm}$ & $300 \mathrm{~mm}$ \\
\hline VRI 8 & MS Sheet & 0.531 & 0.378 & 0.360 & 0.326 & 0.329 & 0.338 \\
\cline { 2 - 9 } & Rubber Sheet & 0.100 & 0.217 & 0.293 & 0.275 & 0.251 & 0.249 \\
\hline CO 6 & MS Sheet & 0.527 & 0.373 & 0.359 & 0.320 & 0.325 & 0.328 \\
\cline { 2 - 9 } & Rubber Sheet & 0.110 & 0.212 & 0.290 & 0.268 & 0.242 & 0.246 \\
\hline \multirow{2}{*}{ TMV 7 } & MS Sheet & 0.531 & 0.378 & 0.360 & 0.326 & 0.329 & 0.338 \\
\cline { 2 - 9 } & Rubber Sheet & 0.110 & 0.210 & 0.291 & 0.277 & 0.250 & 0.246 \\
\hline
\end{tabular}


Fig.1 Length, width and thickness measurement of groundnut seed

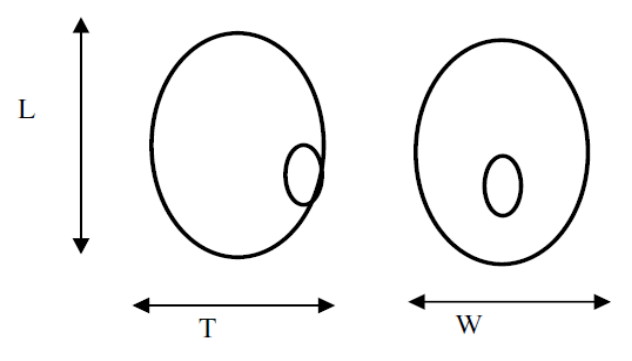

Fig.2 Seed metering disc for groundnut seed

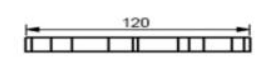

All dimensions are in $\mathrm{mm}$
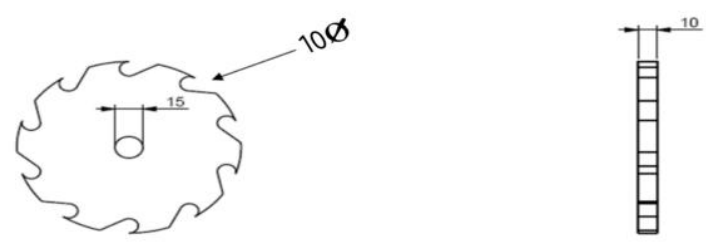

Fig.3 Seed hopper for groundnut seed

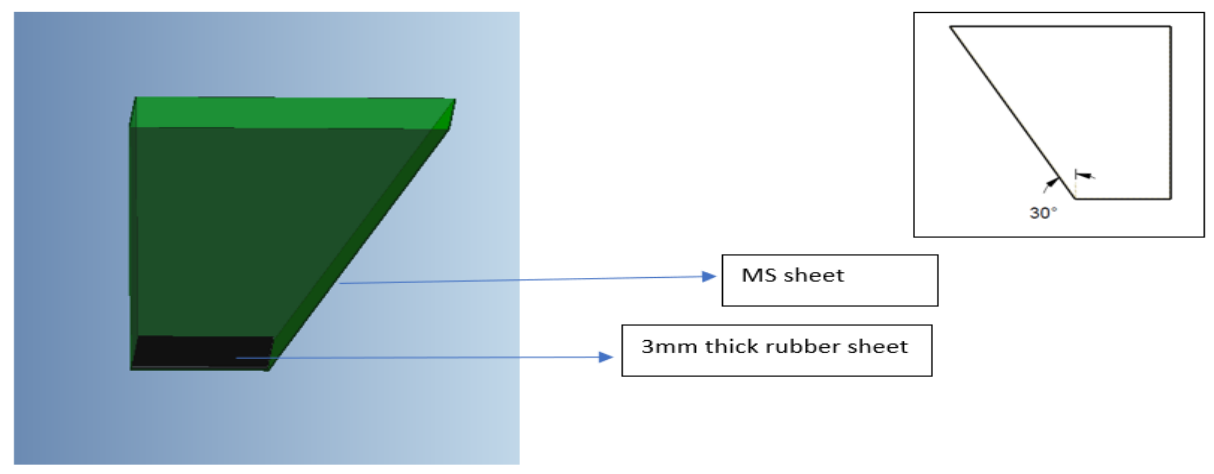

The energy transfer during impact between the falling seed and the seed transfer cup where seed metering disc is placed is related to the coefficient of restitution. Hence, the slope of the seed hopper was kept at $30^{\circ}$ to ensure free flow of seed, which is modestly higher than the average angle of repose of seeds. Furthermore, seeds that fell on the rubber sheet experienced minimum coefficient of restitution compared to that on the mild steel sheet (Table 2). Therefore, a 3 $\mathrm{mm}$ thick rubber sheet was imbedded on the inner surface of the seed transfer cup to minimize seed bouncing. Also, the maximum and minimum values of coefficient of restitution were found for MS sheet and rubber sheet which are 0.531 and 0.100 respectively for VRI 8 at a height of $50 \mathrm{~mm}$. From all the above findings the seeder components (seed metering disc and seed hopper) were designed as shown in figure $2 \&$ figure 3 . 
In conclusion the results of three varieties of groundnut (VRI 8, CO 6 \& TMV 7) were nearly similar so a common metering disc and a common seed hopper for seeder are suitable for all the varieties of groundnut. From all the above physical and frictional properties, the design of the metering disc and the seed hopper was finalized. The Thickness of the metering disc was taken as $10 \mathrm{~mm}$ and the thickness of the seed cell was taken as per roundness of the seed viz., $10 \mathrm{~mm}$, diameter of the seed cell was considered as $10 \mathrm{~mm}$ for easy metering of seeds and also to meter only a single seed in each cell as shown in figure 3 .

Mild steel sheet is selected as material for hopper based on the coefficient of static friction. The inclination of the hopper side wall is considered as $30^{\circ}$ which is modestly higher value than the results of angle of repose.

At the bottom of the hopper box a $3 \mathrm{~mm}$ rubber sheet was attached to reduce the rebounding of seeds as per the results of coefficient of restitution as shown in figure 4 .

\section{References}

Aydin, C., 2007. Some engineering properties of peanut and kernel. J. Food Engg, 79, pp. 810-816.

Bahnasawy, A.H., 2007. Some physical and mechanical properties of garlic. International Journal of Food Engineering, 3(6).

Balasubramanian, S., Sharma, R. and Sardana, V., 2011. Studies on some engineering properties of peanut pod and kernel. Journal of Agricultural Engineering, 48(2), pp.38-42.

Bamgboye, I.A. and Adebayo, S.E., 2012. Seed moisture dependent on physical and mechanical properties of Jatropha curcas.

Davies, R.M., 2009. Some physical properties of groundnut grains. Research Journal of Applied Sciences, Engineering and Technology, 1(2), pp.10-13.

Directorate General of Commercial Intelligence and Statistics (DGCIS). 2018.

Directorate of Economics and Statistics (DES). 2019. 1st Advance Estimates.

Hand book of agricultural engineering. 2013. Indian Council of Agricultural Research, New Delhi.

Jayan, P.R. and Kumar, V.J.F., 2006. Planter design in relation to the physical properties of seeds. Journal of Tropical Agriculture, 42, pp.69-71.

Karaj, S. and Muller, J., 2010. Determination of physical, mechanical and chemical properties of seeds and kernels of Jatropha curcas L. Industrial crops and products, 32(2), pp.129-138.

Kaleemullah, S., 1992. The effect of moisture content on the physical properties of groundnut kernels. Tropical Science (United Kingdom).

Kepner, R. A. Bainer, R. R. and Barger, E. L., 1978. Principles of Farm machinery, 3 rd edition. Westport, CT: AVI publishing company Inc.

Kumar, V.J.F., 1995. Investigation on the effect of crop machine parameters on uniformity of distribution for small seeds in relation to design of pneumatic seed drill (Doctoral dissertation, $\mathrm{PhD}$ thesis, Tamil Nadu Agricultural University, Coimbatore).

krishnappa, M., Maddi, A., Matamari, V. And Kulkarni, P., 2017. Engineering properties of selected groundnut (Arachis hypogea L.) Varieties. International Journal of Agricultural Science and Research, 7(4) pp.203215.

Maduako, J.N. and Hamman, M., 2004. Determination of Some Physical Properties of Three Groundnut Varieties. Nigerian Journal of 
Technology, 24(2), pp.12-28.

Mohsenin, N.N., 1986. Physical properties of plant and animal materials (No. 581.1 M64 1986).

Sahay, K. M. and Singh, K. K. 1994. Unit operations of agricultural processing. Vikas Publishing House Pvt. Ltd. Noida, Uttar Pradesh-201 301, India.

Sharma, V., Das, L., Pradhan, R.C., Naik, S.N., Bhatnagar, N. and Kureel, R.S., 2011. Physical properties of tung seed: An industrial oil yielding crop. Industrial Crops and
Products, 33(2), pp.440-444.

Singh, K.P., Mishra, H.N. and Saha, S., 2010. Moisture-dependent properties of barnyard millet grain and kernel. Journal of Food Engineering, 96(4), pp.598-606.

Waziri, A.N. and Mittal, J.P., 1983. Designrelated physical properties of selected agricultural products. AMA, agricultural mechanization in Asia, Africa and Latin America.

\section{How to cite this article:}

Korla Harshavardhan, S. S. Sivakumar, J. John Gunasekar, P. K. Padmanathan and Alex Albert, V. 2020. Design of Seeder in Relation to the Physical and Frictional Properties of Groundnut Varieties. Int.J.Curr.Microbiol.App.Sci. 9(11): 67-75.

doi: https://doi.org/10.20546/ijcmas.2020.911.007 